\title{
DESAIN INTERIOR LOBBY, BALLROOM, DAN CONVENTION HALL HOTEL YANG RESPONSIF DI MASA PANDEMI
}

\author{
Tegar Aditiya ${ }^{1}$, Choirul Amin ${ }^{2}$, Carina Sarasati ${ }^{3}$ \\ Program Studi Arsitektur, Fakultas Teknik, Universitas Pandanaran Semarang ${ }^{13}$ \\ Jurusan Arsitektur, Fakultas Teknik, Universitas 17 Agustus 1945 Semarang ${ }^{2}$ \\ aditiya@gmail.com ${ }^{1}$ \\ pakminsubali@gmail.com² \\ carinasarasati@gmail.com ${ }^{3}$
}

\begin{abstract}
The Covid-19 pandemic has spread in Indonesia starting in 2020, precisely in March 2020 which is commonly called Corona Virus. This virus spreads to humans who enter the respiratory tract with the first symptoms of flu-like illness to cause severe acute respiratory syndrome (SARS). This virus can be spread through droplets from sneezing or coughing. With the emergence of this outbreak, people are required to carry out daily life activities with health protocols to avoid the spread of the virus. Many businesses, business and tourism sectors have been affected by Covid-19. One of the tourism sectors is hospitality. The tourism sector in the hospitality sector, especially 5-star hotels allow the spread of the virus, because the 5-star hotel environment is often visited by visitors or guests from various cities, provinces, and foreign tourists and the hotel environment is often used as a place for physical contact. Therefore, there is a need for conformity to interior design related to hotel service rooms to minimize physical contact interactions with employees or other hotel visitors, as well as the application of health protocols in every activity in the hotel and related facilities that involve many people.
\end{abstract}

Keywords: Interior Design, Hotel, Pandemic, Health Protocol.

\begin{abstract}
Abstrak
Pandemi Covid-19 sudah menyebar di Indonesia mulai tahun 2020 tepatnya bulan Maret 2020 yang biasa disebut Corona Virus. Virus ini menyebar pada manusia yang masuk ke saluran pernapasan dengan gejala pertama seperti penyakit flu sampai menimbulkan sindrom pernapasan akut berat / Severe Acute Respiration Syndrom (SARS). Virus ini bisa tersebar lewat tetesan cairan dari bersin ataupun batuk. Dengan munculnya wabah ini masyarakat diwajibkan melakukan aktivitas kehidupan sehari - hari dengan protokol kesehatan untuk menghindari penyebaran virus. Banyak sektor usaha, bisnis dan pariswisata yang terdampak karena Covid-19. Salah satu sektor pariswisata adalah perhotelan. Sektor pariwisata dalam lingkup perhotelan khususnya hotel berbintang 5 memungkinkan terjadinya penyebaran virus, karena lingkungan hotel bintang 5 sering dikunjungi oleh pengunjung atau tamu yang berasal dari berbagai kota, provinsi, maupun turis manca negara serta lingkungan hotel yang sering dijadikan tempat berinteraksi kontak fisik. Oleh karena itu perlu adanya kesesuaian terhadap desain interior yang terkait dengan ruang pelayanan hotel untuk meminimalisir interaksi kontak fisik dengan karyawan atau pengunjung hotel lainnya, serta penerapan protokol kesehatan disetiap aktivitas yang ada didalam hotel dan fasilitas terkait yang melibatkan banyak orang.
\end{abstract}

Kata kunci: Desain Interior, Hotel, Pandemi, Protokol Kesehatan. 


\section{PENDAHULUAN}

Virus Corona atau Corona Virus Diseasea (Covid-19) adalah wabah virus yang menyebabkan perubahan tatanan kehidupan diseluruh dunia. Pada akhir tahun 2019 sudah banyak informasi bahwa di luar negeri telah gencar dengan adanya Covid-19 dari negara China yang belum menyebar ke Indonesia hingga terdengar kabar kembali jika Covid-19 sudah menyebar di Indonesia mulai tahun 2020 tepatnya bulan Maret 2020 yang biasa disebut Corona Virus. Pada awal bukan Maret tepat 02 Maret 2020 tercatat Presiden Jokowi menginformasikan adanya ibu dan anak yang terpapar Covid-19 hingga sampai akhir Maret 2020 tercatat 1.528 pasien yang dinyatakan positif terpapar virus ini diantaranya ada 136 pasien yang meniggal dunia. Dengan munculnya wabah ini masyarakat diwajibkan melakukan aktivitas kehidupan sehari - hari dengan protokol kesehatan untuk menghindari penyebaran virus. Virus corona adalah virus yang zoonotik. Ini artinya, virus mulai berkembang dari binatang sebelum sampai menulari manusia. Pada saat telah menular ke manusia, persebaran virus corona dapat lewat droplet pernapasan. semburan bersin atau batuk dari orang yang terkena virus corona dapat melekat pada area suatu brang maupun permukaan kulit manusia. Akhirnya, virus akan pindah saat menyentuh benda atau melakukan interaksi secara langsung antara orang lainnya. Selanjutnya, virus kemudian menyerang manusia saat kondisi badan terkena oleh virus mengenai muka, contohnya bibir, hidung, dan kontak lensa mata. Banyak sektor usaha, bisnis dan pariswisata yang terdampak karena Covid-19. Salah satu sektor pariswisata adalah perhotelan. Sektor pariwisata dalam lingkup perhotelan khususnya hotel berbintang 5 memungkinkan terjadinya penyebaran virus, karena lingkungan hotel bintang 5 sering dikunjungi oleh pengunjung atau tamu yang berasal dari berbagai kota, provinsi, maupun turis manca negara serta lingkungan hotel yang sering dijadikan tempat berinteraksi kontak fisik. Oleh karena itu perlu adanya kesesuaian terhadap desain interior yang terkait dengan ruang pelayanan hotel untuk meminimalisir interaksi kontak fisik dengan karyawan atau pengunjung hotel lainnya, serta penerapan protokol kesehatan disetiap aktivitas yang ada didalam hotel dan fasilitas terkait yang melibatkan banyak orang. Terdapat beberapa ruangan hotel yang berpotensi sebagai area penyebaran Covid-19 area tersebut sering digunakan oleh banyak orang sesuai dengan fungsinya, antara lain area Lobby hotel sebagai area pelayanan saat Check in dan area tamu. Area Ballroom yang difungsikan untuk acara pesta dan area Convention Hall untuk keperluan rapat, pertemuan bisnis dan acara formal untuk pengunjung hotel. Dari beberapa fenomena diatas, maka disusunlah penelitian ini yang bertujuan untuk memberikan informasi terkait desain interior pelayanan hotel bintang 5 di masa pandemi, serta memberikan rekomendasi alternatif terkait desain interior ruang pelayanan hotel dengan mengambil studi kasus berupa 3 objek bangunan hotel di Semarang. Dengan ruang lingkup hotel bintang 5 di Semarang antara lain, Gumaya Tower Hotel, Grand Candi Hotel dan Hotel Ciputra Semarang dan Batasan berupa desain interior Lobby, Ballroom, dan Convention Hall.

TINJAUAN TEORI

Corona Virus Diseasea (Covid-19)

$\overline{\text { Program Studi Arsitektur Universitas Pandanaran | kolaborasi jurnal@unpand.ac.id | } 55}$ 
Infeksi virus Corona bernama Covid-19 (Corona Virus Disease 2019) dan pertama kali muncul di kota Wuhan, China pada akhir Desember 2019. Virus ini berkembang sangat pesat dan telah menyebar ke seluruh atau penjuru dunia, termasuk Indonesia, hanya dalam beberapa bulan. Infeksi tersebut menyebabkan banyak negara menerapkan kebijakan untuk melakukan lockdown guna mencegah penyebaran virus Corona. Di negara kita, Pembatasan Sosial Berskala Besar (PSBB) diberlakukan untuk mengurangi penyebaran virus Corona Coronavirus mungkin merupakan kelompok virus yang dapat mengganggu sistem. Dalam beberapa kasus, virus ini dapat menyebabkan infeksi saluran pernapasan bawah, seperti flu. Namun, virus ini pun dapat menyebabkan infeksi saluran pernapasan tinggi, seperti serangan paru-paru (pneumonia). Virus ini menyebar melalui semburan batuk (droplet) dari saluran, seperti ketika memasuki ruangan tertutup yang penuh sesak dan sirkulasi udara yang tidak teratur atau kontak fisik dengan pasien.

\section{Protokol Kesehatan}

Dibukanya sebagian sektor pariwisata dan perkantoran membuat bisnis hotel kembali beroperasi saat new normal. Namun, tentunya ada komitmen dari manajemen untuk menerapkan aturan baru bagi pengunjung yang akan menginap demi meminimalkan risiko penularan Covid-19. Adapun cara membersihkan dan merawat hotel yang higienis sesuai standar WHO bagi para staff dan tamu hotel terdiri dari 9 hal. 1. Membuat dan Menerapkan Standar Protokol Kesehatan Manajemen hotel perlu merancang aturan keamanan dan keselamatan sesuai protokol kesehatan yang dianjurkan pemerintah dan WHO. Bahkan aturan ini perlu diperketat karena penyebaran virus penyebab Covid-19, masih belum terkendali hingga kini. Guna mencegah hotel Anda menjadi cluster penyebaran coronavirus, maka hotel perlu menyediakan berbagai sarana kesehatan dengan protokol kesehatan ketat, misalnya: - Mewajibkan seluruh staf dan pengunjung menggunakan masker - Staf hotel dengan APD melakukan pengecekan suhu sebelum tamu masuk ke hotel - Memperbanyak wastafel cuci tangan, hand sanitizer, tisu di berbagai area. - Memakai pembersih khusus/disinfektan di guest room dan ruangan lain, dll.

\section{Hotel di Masa Pandemi}

Pandemi COVID-19 terus melanda berbagai negara di dunia. Banyak prediksi bermunculan terkait dunia pasca-epidemi. Para ahli memprediksi akan ada banyak perubahan. Tidak hanya dalam dunia kerja dan hubungan dengan orangorang, tetapi juga dalam desain hotel jangka panjang. per spesialis Lauren Rottet, pademi ini mempengaruhi kesamaan keheningan sebagai bagian dari karakteristik hotel masa depan. Rotter adalah wanita pertama yang dinominasikan sebagai Fellow oleh American Institute of Architects dan Internasional Interior Design Association. la juga merupakan Designer of the Year, Interior Design Hall of Fame, Platinum Circle Member, dan Boutique Designer of the Year. Menurut situs Forbes, ia memprediksi desain hotel akan berubah menjadi lebih ramah terhadap sinar matahari dan lebih bersih. Perhatian juga diberikan pada sirkulasi udara. Udara segar lebih disukai, tetapi udara yang bersikulasi perlu dikurangi. Di masa depan, desain dan furnitur hotel akan berubah. Beberapa fitur ini saat ini diterapkan oleh Belmond Cap Julluca di Anguilla. Tamu dapat check-in dari mana saja di properti yang mereka pilih, mereka bisa langsung masuk ke kamar. Dalam waktu dekat, Rotttet memprediksi banyak tamu hotel bintang 5 akan menerapkan proses remote check-in. Tamu bisa melakukan check in secara daring melalui telepon sebelum kedatangan dengan menggunakan kode untuk mengakses ruangan. 


\section{Elemen Desain Interior}

Design interior adalah suatu cabang ilmu pengetahuan yang mempelajari perencanaan penataan posisi dan perancangan ruangan di dalam sebuah ruangan. Design interior juga dapat mempengaruhi suasana hati bagi penghuninya. Jika Anda tertarik untuk mengatur design interior apartemen atau rumah Anda, terdapat beberapa elemen yang harus Anda perhatikan. Berikut 7 elemen dasar dalam design interior.

1. Space / Ruang

Ruangan merupakan elemen mendasar yang harus diperhatikan dalam design interior. Ruang sendiri terbagi menjadi dua jenis, yaitu ruang 2 dimensi seperti dinding atau lantai, dan ruang 3 dimensi yaitu satu bentuk ruangan utuh yang akan Anda design. Dalam mengatur tata letak suatu ruangan, seorang designer harus mengetahui dengan tepat ukuran dan utilitas ruangan tersebut. Selain itu mereka juga harus tahu bagaimana cara mengisi ruang tersebut untuk meningkatkan nilai estetika di dalamnya.

\section{Line / Garis}

Secara umum, elemen garis dibagi menjadi 3 jenis, yaitu horizontal, vertikal, dan dinamis. Mengetahui bagaimana cara menggunakan garis juga diperlukan ketika mengatur design ruangan. Sebagai contoh, garis vertikal dapat memberi kesan tinggi pada ruangan, sedang garis horizontal dapat digunakan pada dinding lorong yang pendek agar berkesan lebih panjang. Kemudian untuk garis dinamis seperti melengkung atau zig-zag biasanya digunakan untuk menunjukkan suatu energi dinamis dalam ruangan. Biasanya garis dinamis digunakan di dalam ruang kerja atau pusat kebugaran.

\section{Bentuk}

Dalam design interior, elemen bentuk terbagi menjadi dua jenis, yaitu geometric (buatan manusia) dan natural (alami). Elemen bentuk juga dikategorikan sebagai bentuk terbuka dan tertutup. Kamar tidur merupakan elemen bentuk terbuka yang dapat Anda datangi, sedangkan furniture, tanaman, atau benda-benda untuk dekorasi merupakan elemen dengan bentuk tertutup. Pemahaman yang baik mengenai elemen ini sangat penting untuk membangun nuansa ruangan yang diinginkan.

\section{Cahaya}

Baik cahaya natural atau cahaya buatan dapat memberi aksen untuk sebuah ruangan. Cahaya dapat dibagi menjadi tiga kategori, yaitu pencahayaan sesuai fungsi (task lighting), pencahayaan untuk aksen (accent lighting), dan pencahayaan untuk menambah suasana (mood lighting). Saat mengatur pencahayaan, penting bagi Anda untuk mempertimbangkan aktivitas-aktivitas yang akan dilakukan di dalamnya. Sebagai contoh, untuk ruang yang digunakan untuk bekerja, maka membutuhkan pencahayaan yang terang. Berbeda dengan ruang tengah yang dapat diaplikasikan dengan cahaya yang lebih lembut.

\section{Warna}

Warna memiliki kemampuan untuk mengubah suasana di dalam ruangan. Selain itu, warna juga dapat mengubah emosi dan menstimulasi psikologis dari penggunanya. Contohnya, warna hijau dan biru dapat menimbulkan kesan yang tenang sehingga cocok digunakan untuk kamar tidur. Sedangkan warna merah dapat digunakan untuk ruang makan atau dapur karena dapat mendorong nafsu makan. Karena dapat menimbulkan kesan yang berbeda, maka sebaiknya Anda 
memikirkan terlebih dahulu ruangan tersebut akan Anda gunakan untuk aktivitas apa. Setelah itu, pertimbangkan pencahayaan yang akan digunakan karena cahaya juga dapat mempengaruhi persepsi warna. Pertimbangkan juga luas ukuran, jika ruang memiliki ukuran yang sempit sebaiknya gunakan warna-warna yang cerah.

\section{Tekstur}

Tekstur menjadi elemen yang sering terlupakan. Padahal, teksur dapat membawa kesan yang unik pada suatu ruangan. Tekstur memiliki dua bentuk, yaitu teksur visual dan aktual. Tekstur visual adalah teksur yang dapat dilihat oleh mata. Sedangkan tekstur aktual adalah tekstur yang dapat dilihat dan juga diraba. Sama seperti elemen warna dan cahaya, penggunaan tekstur juga dapat memicu respon emosional. Seperti tekstur kasar dapat menunjukkan kesan yang kokoh, sedang tekstur halus menunjukkan keanggunan dan formalitas.

\section{Pola}

Pola dapat menambah daya tarik ruangan. Elemen ini dapat Anda buat menggunakan wallpaper, karpet, kain, dan lain-lain. Saat Anda ingin menambahkan pola, pertimbangkan gaya dan ukuran ruangan. Jika Anda menyukai gaya yang feminin, Anda dapat menggunakan pola bunga-bunga di dalam ruangan. Meskipun pola dapat membangun gaya yang berbeda, namun perlu diperhatikan untuk tidak menambahkan terlalu banyak pola di ruangan kecil karena dapat memberi kesan yang berlebihan.

\section{METODOLOGI PENELITIAN}

Penelitian tentang perubahan desain hotel selama penelitian ini menggunakan pendekatan kualitatif melalui analisis isi dari berbagai sumber. Lebih khusus lagi, penelitian ini berpredikat pada penelitian kualitatif, khususnya melalui kajian terhadap dokumen-dokumen yang relevan dan bermanfaat terkait dengan hotelhotel di Indonesia. Dokumen yang digunakan, misalnya, berasal dari praktik lapangan oleh para ahli yang terkait dengan perancangan desain bangunan hotel dalam bentuk artikel, jurnal, berita, dan hasil penelitian terkait, serta sumber pengetahuan lainnya. informasi dan data tersebut kemudian dianalisis secara kualitatif, dengan menafsirkan dan mengaitkan hubungan antara teori, kenyataan dan praktik di lapangan. berikut mungkin pembahasan dari temuan info yang dilakukan terkait pengaruh pandemi terhadap sektor pariwisata di Indonesia.

\section{HASIL PEMBAHASAN}

\section{Gumaya Tower Hotel}

Sebelum dan setelah masa pandemi, Gumaya Tower Hotel telah menerapkan sistem booking hotel secara online melalui berbagai macam aplikasi dimana setiap tamu hotel yang akan menginap dapat memesan kamar hotel secara online tanpa harus berinteraksi secara langsung dengan pihak hotel di resepsionis ataupun menunggu proses pemesanan kamar di lobby yang cukup memakan waktu. Menggunakan aplikasi booking hotel secara online sangat memudahkan dan menghemat waktu bagi para tamu hotel terutama di kalangan pebisnis yang sibuk dengan perkerjaan. 

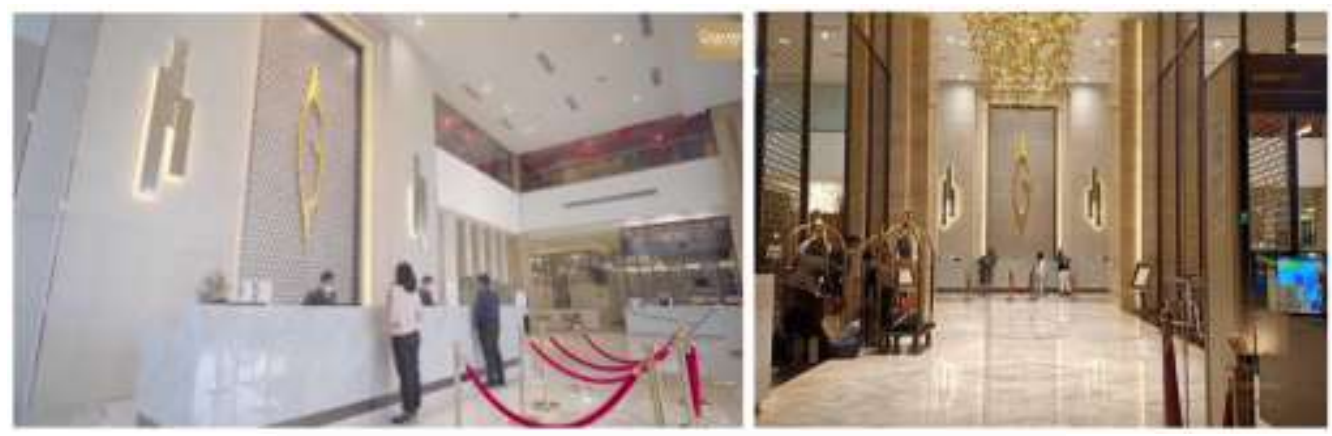

Gambar 1. Resepsionis Gumaya Hotel Tower

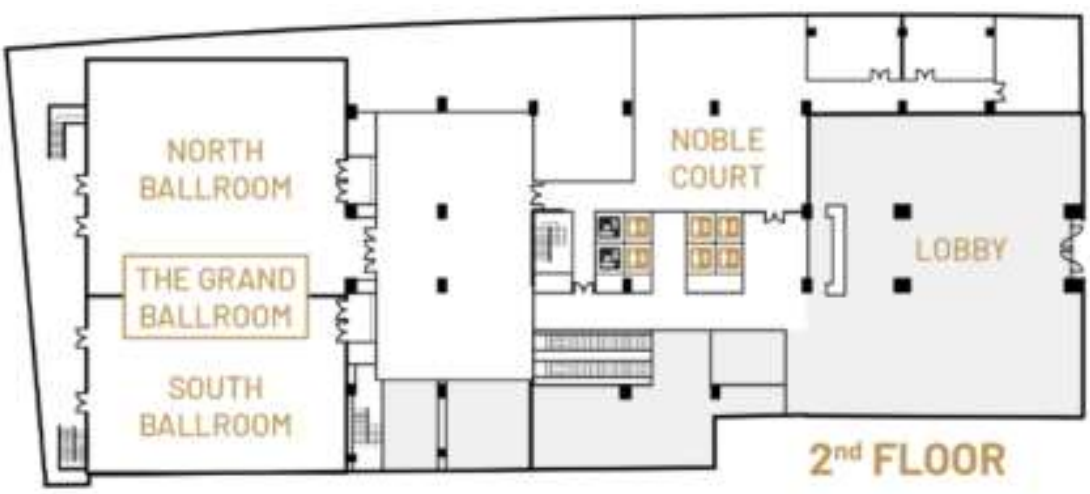

3. emergency exit
I. fire extinguisher
I. fire hose cabinet

if gent restroom

[1] guest lift

i ladies restroom

F landing lift

Gambar 2. Denah
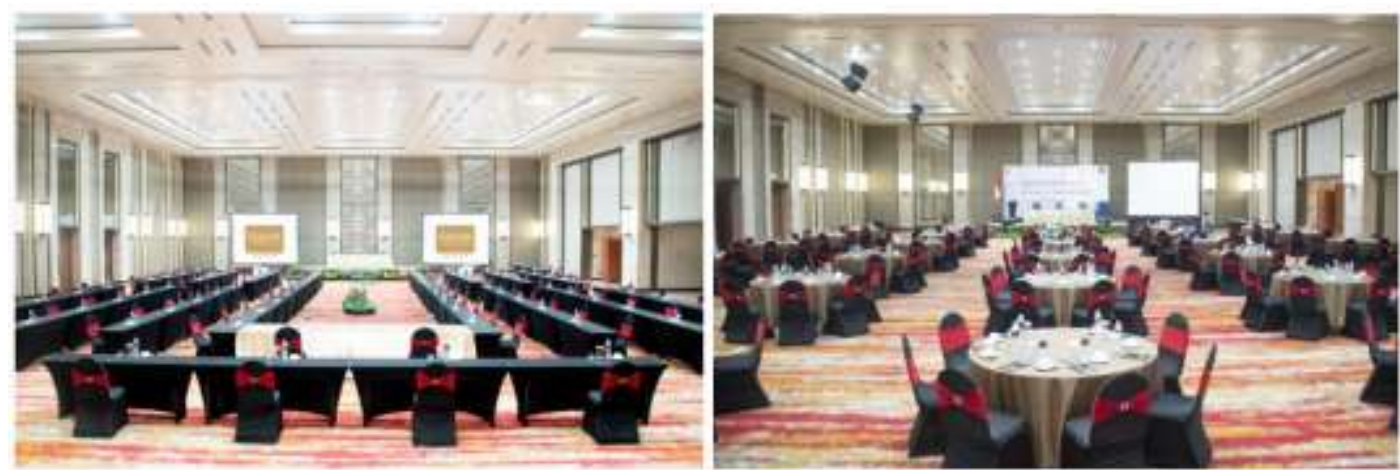

Gambar 3. Conevtion Hall 
Tabel 1. Elemen Interior Gumaya Tower Hotel

\begin{tabular}{|c|c|c|c|c|c|c|c|c|}
\hline \multirow{2}{*}{ No } & \multirow{2}{*}{ Foto Ruangan } & \multicolumn{7}{|c|}{ Elemen Interior } \\
\hline & & Ruang & Garis & Bentuk & Cahaya & Warna & Tekstur & Pola \\
\hline \multirow{2}{*}{1} & & V & V & V & V & N & V & V \\
\hline & & & & & & & & \\
\hline \multirow{2}{*}{2} & & V & V & V & V & V & V & V \\
\hline & Ballroom & & & & & & & \\
\hline \multirow[t]{3}{*}{3} & & & & & & & & \\
\hline & & V & V & V & V & V & V & V \\
\hline & Convention & & & & & & & \\
\hline
\end{tabular}

Tabel 2. Responsibility Interior terhadap Pandemi di Gumaya Tower Hotel

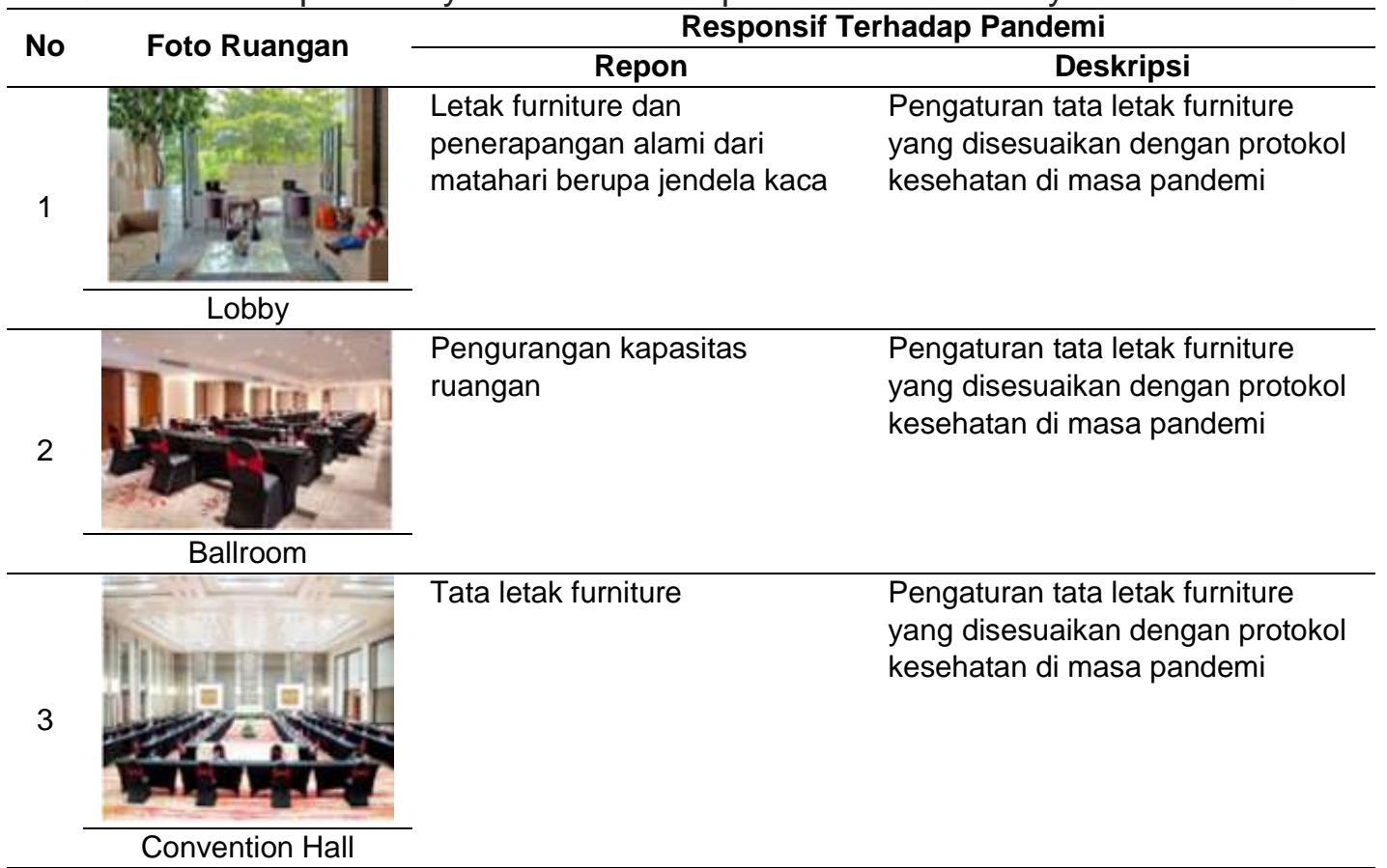

\section{Grand Candi Hotel}

Grand Candi Hotel terletak di Jl. Sisingamangaraja No.16, Kaliwiru, Kec. Candisari, Kota Semarang, Jawa Tengah 50232. Bangunan hotel ini difungsikan sebagai penginapan dengan menawarkan berbagai macam fasilitas lengkap bagi para tamu di kalangan atas, hotel ini tergolong hotel bintang 5 jika dilihat dari berbagai fasilitas yang ditawarkan seperti Fitness Center, Ballroom, Spa, Swimming Pool, dan Power Swing. Guma memastikan keamanan dan 
kenyamanan tamu, manajemen hotel senantiasa protokol kesehatan secara tertib sejak periode awal pandemi covid-19 mewabah di Indonesia dan terus melakukan peningkatan protokol. Bahkan Grand Candi Hotel sudah menerapkan era touchless (aman tanpa menyentuh) di seluruh area hotel.
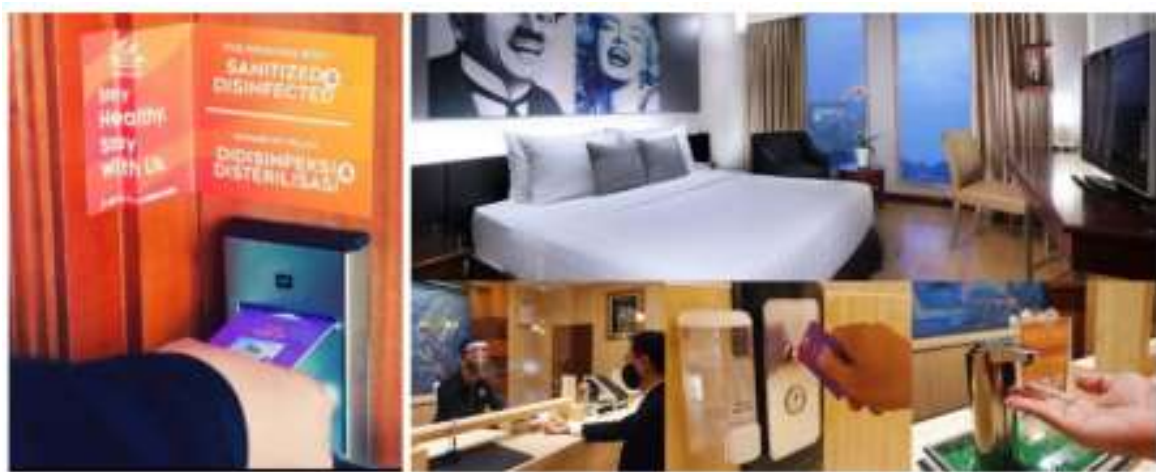

Gambar 4. Penerapan Era Touchless (Tanpa Menyentuh)

Protokol kesehatan dan kebersihan yang diterapkan oleh Hotel Grand Candi antara lain mewajibkan tamu, pengunjung dan staf untuk selalu menggunakan masker di area publik, memeriksa tanda-tanda vital pintu masuk sekecil apa pun, menjaga jarak minimal 1 meter dari orang, menekan tombol lift menggunakan kartu kunci yang disemprotkan . desinfektan.
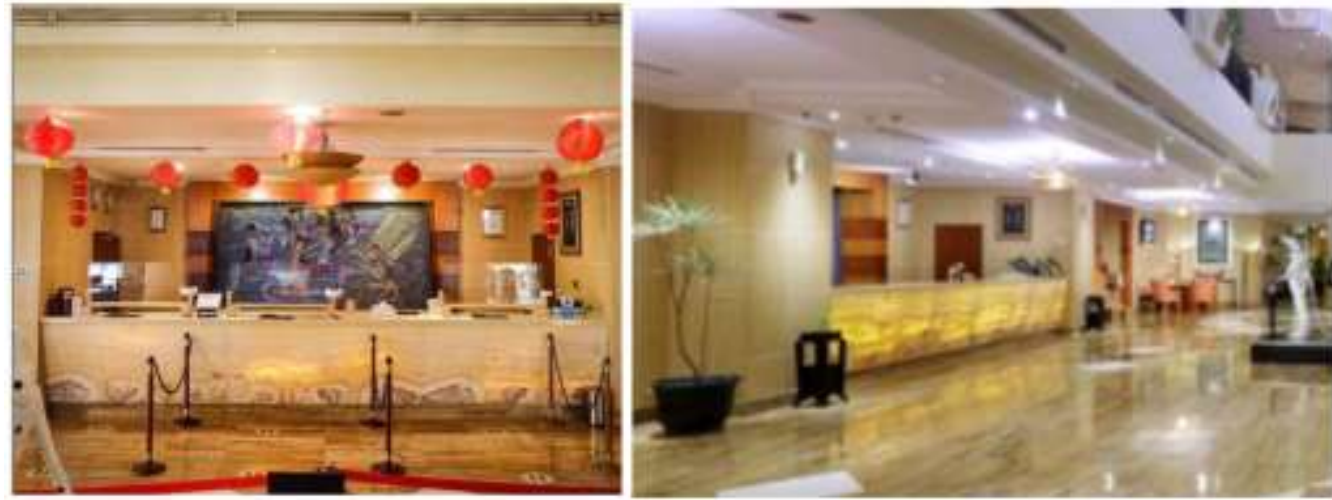

Gambar 5. Perubahan Desain Interior Lobby sebelum dan setelah Pandemi di Grand Candi Hotel 
Tabel 3. Elemen Interior Grand Candi Hotel

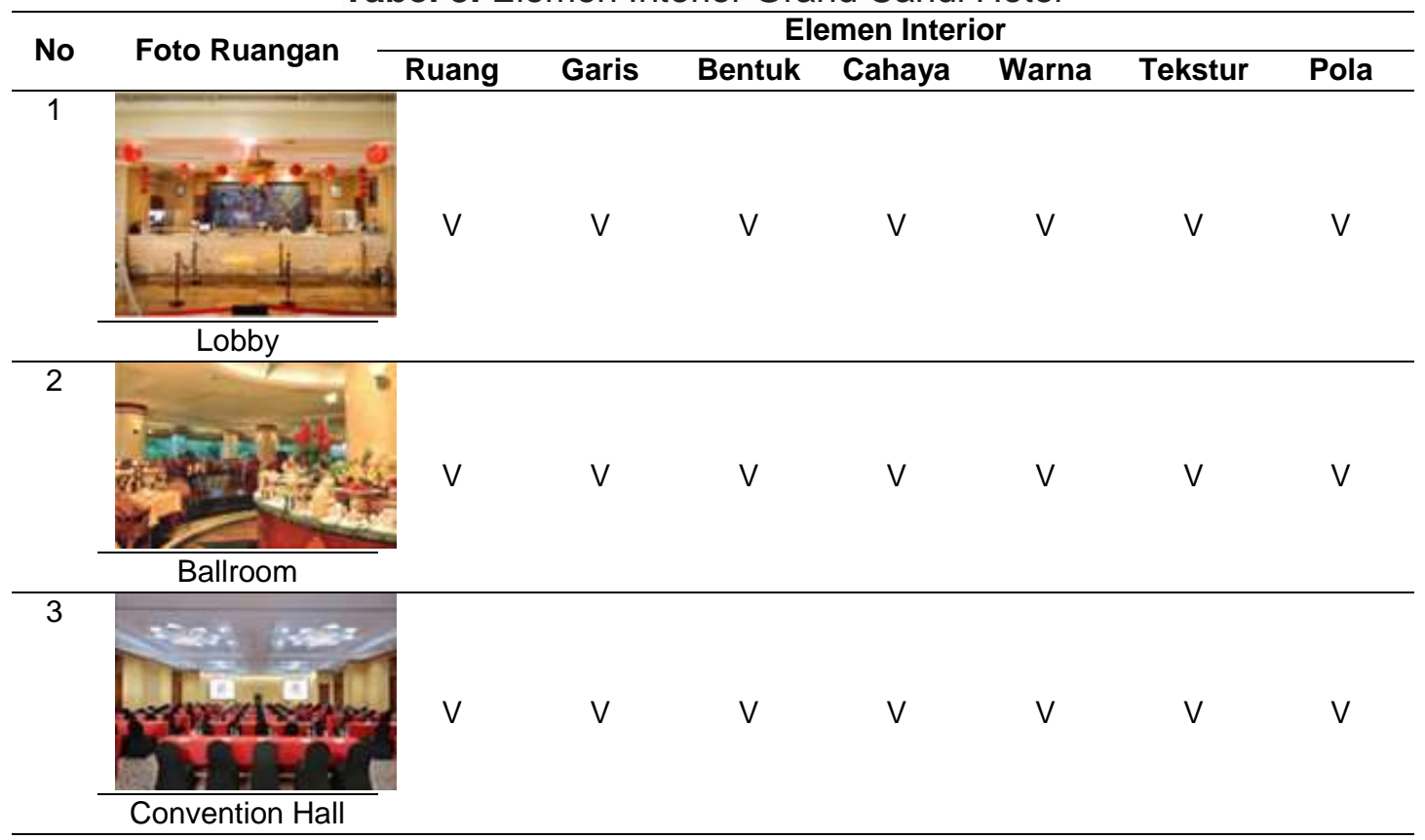

Tabel 4. Responsibility Interior terhadap Pandemi di Grand Candi Hotel

\begin{tabular}{|c|c|c|c|}
\hline \multirow{2}{*}{ No } & \multirow{2}{*}{ Foto Ruangan } & \multicolumn{2}{|c|}{ Responsif Terhadap Pandemi } \\
\hline & & Repon & Deskripsi \\
\hline 1 & & $\begin{array}{l}\text { Pembagian jalur antrean di } \\
\text { area lobby receptionist }\end{array}$ & $\begin{array}{l}\text { Pembagian jalur antrean di area } \\
\text { lobby receptionist yang } \\
\text { bertujuan untuk mengatur jarak } \\
\text { interaksi }\end{array}$ \\
\hline 2 & & $\begin{array}{l}\text { Pengurangan kapasitas } \\
\text { ruangan }\end{array}$ & $\begin{array}{l}\text { Pengaturan tata letak furniture } \\
\text { yang disesuaikan dengan } \\
\text { protokol kesehatan di masa } \\
\text { pandemi }\end{array}$ \\
\hline 3 & Dalinuoum & Tata letak furniture & $\begin{array}{l}\text { Pengaturan tata letak furniture } \\
\text { yang disesuaikan dengan } \\
\text { protokol kesehatan di masa } \\
\text { pandemi }\end{array}$ \\
\hline & Conventic & & \\
\hline
\end{tabular}

\section{Hotel Ciputra Semarang}

Letaknya yang berada dipusat kota Semarang yang beralamat di Jl. Simpang Lima No.1, Pekunden, Kec. Semarang Tengah, Kota Semarang, Jawa Tengah 50134, memiliki nilai tambah tersendiri untuk Hotel Ciputra ditambah dengan rate bintang 5 dengan didukung berbagai macam fasilitas hotel yang ditawarkan semakin membuat Hotel Ciputra semakin diminati oleh para tamu menginap di kalangan pebisnis maupun turis mancanegara sebagai salah satu alternatif penginapan saat berkunjung di Semarang. Di masa pandemi saat ini General Manager Hotel Ciputra Michael G. Perdikaris mengatakan, penggunaan GeNose C19 ini untuk keamanan tamu dan karyawan hotel. "Pandemi telah mendorong

62 | Program Studi Arsitektur Universitas Pandanaran | kolaborasi jurnal@unpand.ac.id 
adanya pedoman gaya hidup baru bagi kita semua, di mana standar keselamatan dan kebersihan sangat penting dalam menentukan tujuan perjalanan para tamu, serta cara kita melakukan aktivitas," katanya, belum lama ini.

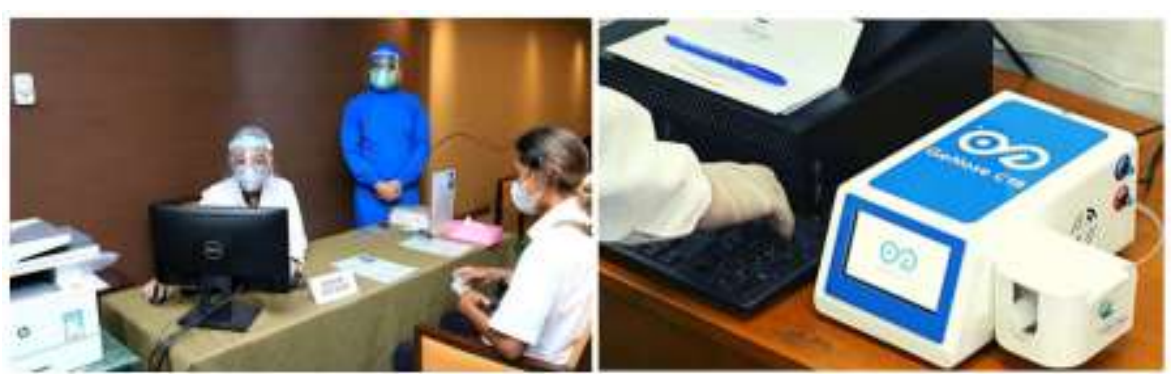

Gambar 6. Pemeriksaan test Covid-19 GeNose C19 di Hotel Ciputra

Selain penerapan protokol kesehatan yang dilakukan pihak Hotel Ciputra Semarang, perubahan desain interior pada ruang meeting juga dikondisikan sedemikian rupa dengan mengatur jarak letak furniture yang bertujuan untuk tetap menjaga jarak antar pengguna ruangan, agar meminimalisir kontak fisik yang terjadi.
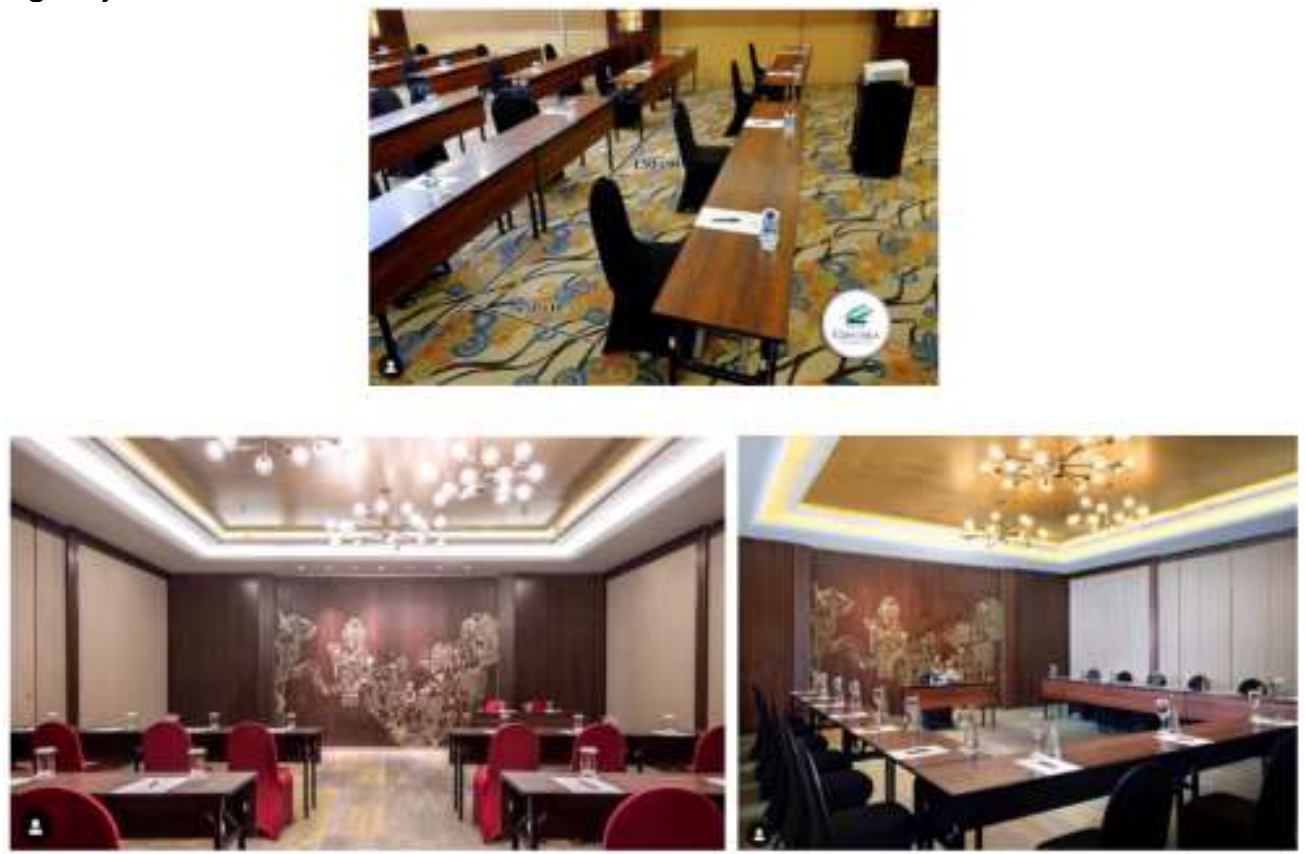

Gambar 7. Perubahan Interior Convention Hall di Hotel Ciputra Semarang, sebelum dan setelah Pandemi 
Tabel 5. Elemen Interior Hotel Ciputra Semarang

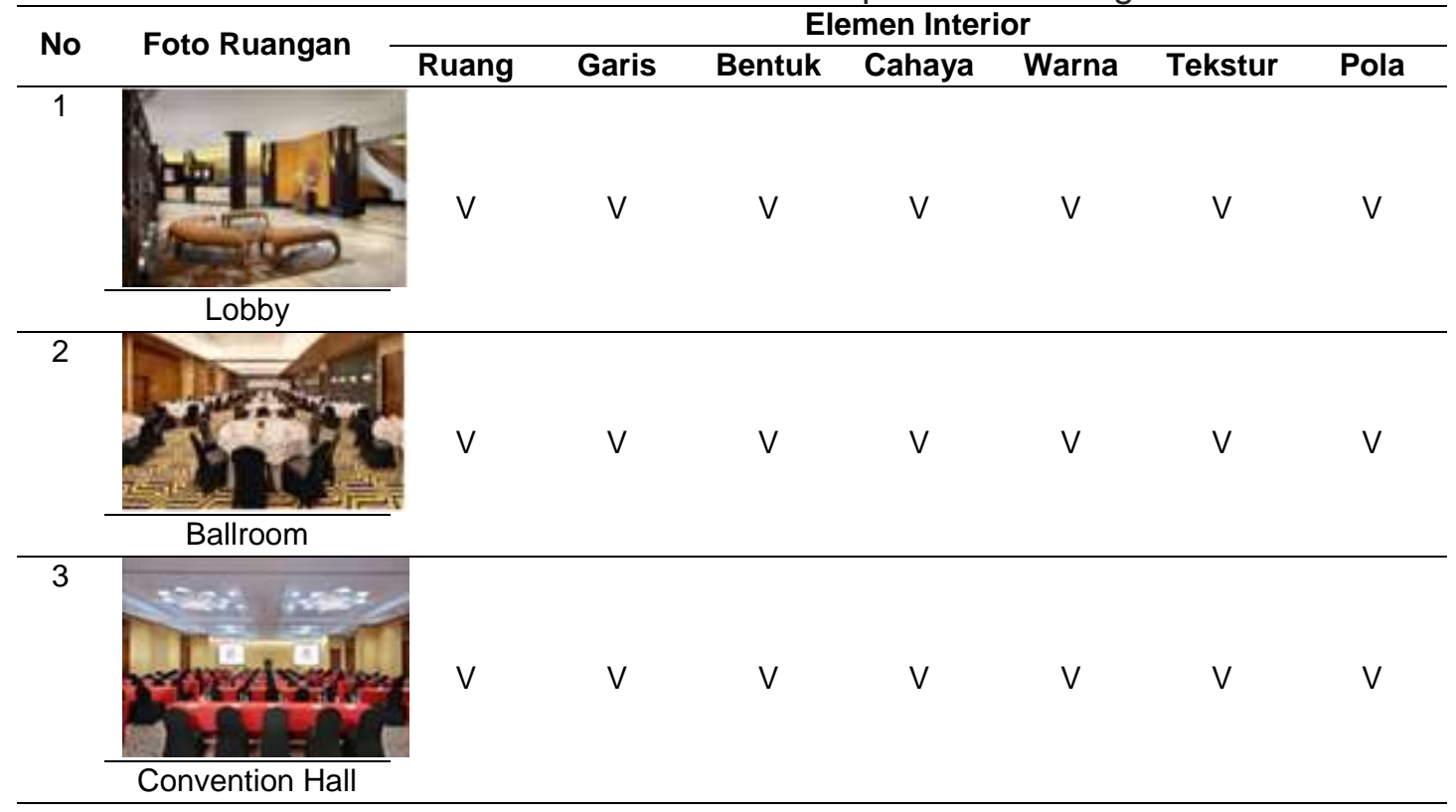

Tabel 6. Responsibility Interior terhadap Pandemi di Hotel Ciputra Semarang

\begin{tabular}{|c|c|c|c|}
\hline \multirow{2}{*}{ No } & \multirow{2}{*}{ Foto Ruangan } & \multicolumn{2}{|c|}{ Responsif Terhadap Pandemi } \\
\hline & & Repon & Deskripsi \\
\hline 1 & & Pengurangan furniture & $\begin{array}{l}\text { Pengurangan jumlah furniture } \\
\text { yang bertujuan untuk } \\
\text { memperluas ruangan sehingga } \\
\text { tidak menyebabkan kerumunan }\end{array}$ \\
\hline & Lo & & \\
\hline 2 & & $\begin{array}{l}\text { Pengurangan kapasitas } \\
\text { ruangan }\end{array}$ & $\begin{array}{l}\text { Pengaturan tata letak furniture } \\
\text { yang disesuaikan dengan } \\
\text { protokol kesehatan di masa } \\
\text { pandemi }\end{array}$ \\
\hline 3 & & Tata letak furniture & $\begin{array}{l}\text { Pengaturan tata letak furniture } \\
\text { yang disesuaikan dengan } \\
\text { protokol kesehatan di masa } \\
\text { pandemi }\end{array}$ \\
\hline
\end{tabular}

\section{KESIMPULAN}

Munculnya fenomena pandemi Covid-19 saat ini, membawa dampak perubahan pada desain interior ruang hotel yang menjadi latar belakang penelitian ini khusunya dalam lingkup hotel bintang 5 . Berdasarkan penelusuran data terkait judul dan proses analisa yang telah dilakukan, sehingga memperoleh hasil sesuai tujuan penelitian ini yang akan disimpulkan sebagai berikut :

1. Dampak Pandemi terhadap Desain Interior Hotel Bintang 5

64 | Program Studi Arsitektur Universitas Pandanaran | kolaborasi_jurnal@unpand.ac.id 
- Area peneriman tamu / Receptionist terdapat pembatas jalur antrean pengunjung dan jalur antrean terdapat tanda yang berfungsi untuk menjaga jarak bagi pengunjung.

- Area ruang pertemuan seperti ruang rapat / meeting room, ruang pertemuan / Ballroom terdapat pada perletakan furniture meja dan kursi yang diatur dengan jarak minimal $1-1,5 \mathrm{~m}$ dan posisi meja dibuat bershaff.

- Beberapa hotel telah menyediakan ruangan khusus untuk digunakan ruang test Covid-19.

\section{Penerapan Protokol Kesehatan Terhadap Desain Hotel Bintang 5}

- Penyediaan wastafel di area pintu masuk hotel sebagai area cuci tangan.

- Penyediaan handsanitizer di beberapa area seperti, area pintu masuk yang dekat dengan wastafel, area resepsionis, pintu masuk kamar hotel, serta di dekat pintu akses masuk lift.

- Penyediaan area khusus untuk pengecekan suhu badan di dekat akses masuk hotel.

- Menjaga jarak dengan mengatur ulang posisi furniture terutama pada area - area yang sering digunakan untuk pertemuan banyak orang.

- Penyediaan pembatas transparan di area Receptionist agar tidak terjadi kontak langsung antara pihak hotel dengan pengunjung.

Tabel 7. Kesimpulan

\begin{tabular}{|c|c|c|}
\hline No & Objek Penelitian & $\begin{array}{l}\text { Responbility Interior Lobby, Ballroom dan } \\
\text { Convention Hall terhadap pandemi }\end{array}$ \\
\hline 1 & naya Tower Hote & $\begin{array}{l}\text { Interior Gumaya Tower Hotel sesuai dengan batasan } \\
\text { penelitian, memliki elemen interior yang sesuai } \\
\text { dengan } 7 \text { elemen desain interior dan memperhatikan } \\
\text { protokol kesehatan dari pemerintah }\end{array}$ \\
\hline 2 & Grand Candi Hotel & $\begin{array}{l}\text { Interior Grand Candi Hotel sesuai dengan batasan } \\
\text { penelitian, memiliki elemen interior yang sesuai } \\
\text { dengan } 7 \text { elemen desain interior berdasarkan } \\
\text { landasan teori dan telah menerapkan protokol } \\
\text { kesehatan di setiap interior ruangan yang digunakan } \\
\text { orang banyak }\end{array}$ \\
\hline 3 & 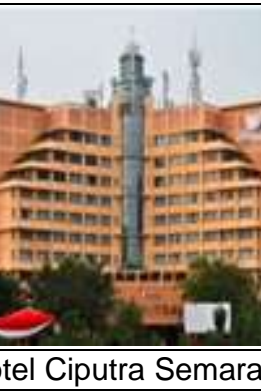 & $\begin{array}{l}\text { Interior Hotel Ciputra sesua dengan batasan } \\
\text { penelitian, memiliki elemen interior yang sesuai } \\
\text { dengan } 7 \text { elemen desain interior berdasarkan } \\
\text { landasan teori dan telah menerapkan protokol } \\
\text { kesehatan di setiap interior ruang yang digunakan } \\
\text { orang banyak }\end{array}$ \\
\hline
\end{tabular}




\section{DAFTAR PUSTAKA}

Adeline, Tasya. )2019. Interior Design Refurbishment of Ciputra Hotel. Jakarta : uph.edu

Anonim. (2020). Hotel di Masa Pandemi. Indonesia : unileverprofessional.com Anonim. (2017). Elemen - Elemen Interior. Maisonderes.com Indina. (2020). City Hotel Di Kota Semarang. Semarang : ejournal2.undip.ac.id Kaniasari, Mardotillah. (2021). Penerapan Protokol Kesehatan Hotel Sebagai Langkah Preventif pada Masa Depan. Medan : poltekparmedan.ac.id

Mahendraswara, Mudiantono. (2020) Studi Terhadap Kualitas Pelayanan Di Hotel Grand Candi Semarang. Semarang : Undip.ac.id.

Rottet, International Interior Design Association, Texas, USA.

Siti Sarah Rayhana. (2017). Perancangan Interior Ruang Publik Kondominium Dan Apartment Ciputra. Yogyakarta : digilib.isi.ac.id 